\title{
PENYELESAIAN KASUS PELANGGARAN HAM PADA MASA RASULULLAH SAW.
}

\author{
Ikhwan \\ Fakultas Ushuluddin IAIN Imam Bonjol \\ Jl. Mahmud Yunus, Lubuk Lintah, Padang, 25153 \\ e-mail: ikhwan_matondang@yahoo.co.id
}

\begin{abstract}
Abstrak: Salah satu prinsip dasar ajaran Islam adalah penghargaan terhadap Hak Asasi Manusia (HAM) yang meliputi penghargaan terhadap agama, jiwa, akal, keturunan dan harta. Pada masa Nabi SAW. sendiri penegakan terhadap pelanggaran ini dapat menjadi inspirasi bagi penegakan HAM pada masa sekarang. Dalam tulisan ini, penulis membahas tentang pengadilan HAM di dalam sistem peradilan Islam dan mengidentifikasi bentuk dan mekanisme penyelesaian kasus-kasus pelanggaran HAM. Penulis menemukan bahwa penyelesaian kasus pelanggaran hak asasi manusia dilaksanakan dengan tiga metode. Pertama, metode berperkara biasa di pengadilan yang diakhiri dengan keputusan hakim. Kedua, metode berperkara biasa di pengadilan yang diakhiri dengan ishlâh (perdamaian). Ketiga, metode pengungkapan kebenaran dan rekonsiliasi para pihak, tanpa melalui proses berperkara di pengadilan.
\end{abstract}

\begin{abstract}
The Settlement of Human Right Violation Case in the Time of Prophet pbh. One of the basic principles of Islamic Teachings is the serious concern on the protection of human rights which include safeguarding religion, life, intellect, descendants and possessions. Human right violence law enforcement during the time of the Prophet may become a source of inspiration for the current problems. In this essay the author discusses human rigth court of justice in Islamic system of judicature and identify the form and mechanism of cases of human right violence settlements. The author finds that dispute settlements are carried out as in the normal litigation by bringing the case to the court which then followed by either decision by the judge or reconciliation. In addition, it may also be settled by reconciliation of the parties without filing the case to the court.
\end{abstract}

Kata Kunci: hukum Islam, pelanggaran HAM, Rasulullah SAW.

\section{Pendahuluan}

Usaha terpenting yang dilakukan dalam rangka perlindungan hak asasi manusia di antaranya adalah mengusut, mengadili, dan menyelesaikan kasus-kasus pelanggaran 
hak asasi manusia. Upaya bersifat preventif, seperti pendidikan, penyuluhan, dan pembuatan peraturan-peraturan tentang Hak Asasi Manusia (HAM) tidak dapat melindungi hak asasi manusia secara baik dan maksimal tanpa dibarengi dengan pendekatan represif dalam bentuk pemberian sanksi hukum melalui lembaga peradilan. Penyelesaian kasus pelanggaran hak asasi manusia secara adil dan beradab serta penerapan sanksi hukum bagi pelakunya dapat menjadi pendidikan hukum yang baik bagi masyarakat, di samping dapat menimbulkan efek jera kepada pelakunya dan efek takut bagi orang yang berniat melakukannya. Semua upaya perlindungan hak asasi manusia yang bersifat represif tersebut hanya dapat dilakukan secara baik dan benar melalui proses berperkara di pengadilan.

Pelaksanaan peradilan dalam rangka penegakan dan perlindungan hak asasi manusia telah dimulai sejak berakhirnya Perang Dunia II di mana pembunuhan masal, pemerkosaan, pemusnahan etnis, dan lainnya yang dilakukan oleh NAZI-Jerman diadili oleh Mahkamah Militer Internasional (International Military Tribunal) di Nuremberg mulai Oktober 1945. Para petinggi NAZI didakwa telah melakukan kejahatan perang (war crime), kejahatan terhadap kemanusiaan (crimes against humanity), dan kejahatan terhadap perdamaian (crimes against peace). Pada perkembangan selanjutnya, pengadilan ini diteruskan oleh pemerintah Republik Federasi Jerman. Sementara itu, Mahkamah Militer Internasional yang sama juga didirikan di Tokyo untuk mengadili pelanggaran hak asasi manusia yang dilakukan oleh para pemimpin Jepang. ${ }^{1}$

Pada tahun 1993, PBB membentuk Pengadilan International (International Tribunal) untuk bekas Yugoslavia guna mengadili orang-orang yang bertanggung jawab atas terjadinya pelanggaran serius terhadap hukum humaniter dalam wilayah bekas Yugoslavia sejak tahun 1991. ${ }^{2}$ Para terdakwa antara lain Slobodan Milocevic (Presiden Yugoslavia), Milan Milutinovic (Presiden Serbia), Nikola Sainovic (Deputi Perdana Menteri Yugoslavia), Dragoljub Ojdanic (Kepala Staf Umum Angkatan Bersenjata Yugoslavia), dan Vlajko Stoplijkovic (Menteri Dalam Negeri Serbia). ${ }^{3}$ Pengadilan ini juga mengadili Milan Babic, pemimpin pemberontak Serbia-Kroasia, serta memburu pemimpin pemberontak Serbia-Bosnia, Radovan Karadzic dan Ratko Mladic. Milan Babic akhirnya tewas bunuh diri dalam sel tahanan pada awal Maret 2006 dan Slobodan Milocevic juga tewas karena serangan jantung dalam tahanan pada 11 Maret $2006 .^{4}$

\footnotetext{
${ }^{1}$ Abdul Hakim Garuda Nusantara, "Mengadili Kasus-Kasus Pelanggaran Hak Asasi Manusia: Pengalaman Beberapa Negara," Makalah pada Seminar Nasional Rancangan Undang-Undang tentang Pengadilan Hak Asasi Manusia (Jakarta: Direktorat Jenderal Hukum dan Perundang-undangan Departemen Hukum dan Perundang-undangan R.I., 16 Februari 2000), h. 1.

"Statute of the International Tribunal for Former Yugoslavia," Adopted 25 May 1993 as Amended 13 May 1998.

${ }^{3}$ Djoko Soegianto, "Usaha untuk Mengenal Pengadilan HAM," Makalah Pelatihan HAM bagi Calon Hakim dan Hakim Ad Hoc di Hotel Santika 4-10 Nopember 2001 (Jakarta: Departemen Kehakiman dan HAM R.I., 2001), h. 26-27.

4"Pembantai Muslim Bosnia Tewas di Sel," dalam Indopos (Jakarta, 12 Maret 2006).
} 
Pada tahun 1994, PBB membentuk Pengadilan Internasional untuk wilayah Rwanda guna mengadili orang-orang yang bertanggung jawab atas terjadinya genosida dan pelanggaran serius terhadap Hukum Humaniter Internasinal dalam wilayah Rwanda dan negara-negara tetangganya. ${ }^{5}$ Pengadilan Internasional ini menyeret Jean Kambada (mantan Perdana Menteri Rwanda), Omar Serushago (pemimpin milisi Hutu), dan Ignace Bagilisheina sebagai terdakwa dengan tuduhan melakukan genosida dan kejahatan terhadap kemanusiaan yang menewaskan sekitar 500.000 penduduk Rwanda, terutama dari suku minoritas Tutsi, sekitar tahun $1994{ }^{6}$

Mahkamah Internasional Nuremberg maupun Mahkamah Internasional di Rwanda dan bekas Yugoslavia tidak menyebutkan dirinya sebagai pengadilan HAM. Namun, proses peradilan yang terjadi diketahui secara luas sebagai proses peradilan terhadap para terdakwa yang melakukan kejahatan terhadap kemanusiaan dan perdamaian. Jadi, esensinya bukan terletak pada nama pengadilan tersebut, tetapi pada peran dan kompetensinya. ${ }^{7}$

Di samping praktik pengadilan kasus pelangggaran HAM berskala internasional di atas, beberapa negara sebenarnya juga memiliki pengalaman mengadili kasus pelanggaran HAM, seperti di Yunani dan Argentina. Pembentukan pengadilan hak asasi manusia oleh PBB untuk Timor-Timur sempat menjadi wacana karena ada dugaan kuat telah terjadi berbagai pelanggaran HAM yang serius pasca jajak pendapat. Keinginan itu mengendur setelah pemerintah Republik Indonesia melakukan tindakan-tindakan nyata untuk mengadili sendiri kasus dugaan pelanggaran HAM tersebut melalui suatu Pengadilan Hak Asasi Manusia Ad Hoc yang diselenggarakan di Jakarta.

Bila ditelusuri lebih jauh, eksistensi pengadilan HAM sesunguhnya memiliki akar sejarah yang panjang. Beberapa tradisi budaya dan sistem hukum, seperti Romawi, Persia, Arab Jahiliyah, dan Islam, sejak zaman dahulu tercatat mempunyai aturan dan lembaga yang menjalankan peran sebagai pengadilan HAM. Kekayaan tradisi budaya dan sistem hukum yang ada tersebut perlu dipelajari dan diteliti sehingga dapat dimanfaatkan untuk pengembangan lembaga pengadilan HAM pada masa yang akan datang.

Untuk itu, tulisan ini membahas tentang pengadilan HAM dalam sistem peradilan Islam, yaitu menjelaskan bagaimana kasus-kasus pelanggaran HAM diselesaikan dalam kerangka hukum Islam berdasarkan data-data yang diperoleh dari al-Qur'an, Sunnah, kitabkitab fiqih dan sejarah. Pembahasan dimulai dari menentukan unsur dan kriteria kasus pelanggaran HAM. Kemudian dipaparkan kasus-kasus yang pernah diadili di peradilan Islam. Selanjutnya dijelaskan bagaimana bentuk dan mekanisme penyelesaian kasus-kasus tersebut.

5"Statute of the International Tribunal for Rwanda, 1994".

6"Pengadilan Paling Akhir", dalam Gatra (Jakarta, 29 Januari 2000), h. 39-40; Soegianto, "Usaha untuk Mengenal Pengadilan," h. 27-28

${ }^{7}$ Garuda Nusantara, "Mengadili Kasus," h. 2 
Ikhwan: Penyelesaian Kasus Pelanggaran HAM Pada Masa Rasulullah SAW.

\section{Pelanggaran Hak Asasi Manusia}

Undang-Undang Nomor 39 Tahun 1999 tentang Hak Asasi Manusia memuat definisi yang cukup baik tentang pelanggaran hak asasi manusia, yaitu:

Setiap perbuatan seorang atau sekelompok orang termasuk aparat negara, baik disengaja maupun tidak disengaja atau kelalaian, yang secara melawan hukum mengurangi, menghalangi, membatasi, dan atau mencabut hak asasi manusia seorang atau sekelompok orang yang dijamin oleh undang-undang ini dan tidak mendapatkan atau dikhawatirkan tidak akan memperoleh penyelesaian hukum yang adil dan benar berdasarkan mekanisme hukum yang berlaku. (Pasal 1 angka 6).

Menurut definisi ini, pelanggaran hak asasi manusia adalah setiap perbuatan yang merugikan hak asasi manusia yang dijamin oleh Undang-Undang Nomor 39 Tahun 1999. Perincian hak asasi manusia yang dijamin tersebut diatur dalam bab III pasal 9 sampai pasal 66 yang meliputi hak hidup, hak berkeluarga dan melanjutkan keturunan, hak mengembangkan diri, hak memperoleh keadilan, hak atas kebebasan pribadi, hak atas rasa aman, hak atas kesejahteraan, hak turut serta dalam pemerintahan, hak-hak wanita, dan hak-hak anak.

Definisi di atas menyebutkan bahwa subjek pelaku pelanggaran hak asasi manusia dapat berupa individu atau sekelompok orang yang secara bersama-sama melakukan suatu pelanggaran hak asasi manusia. Penambahan kata-kata “...termasuk aparat negara ...." merupakan suatu penekanan dan perhatian khusus karena secara faktual, pelanggaran hak asasi manusia banyak dilakukan oleh aparat negara. Penekanan ini merupakan salah satu ciri khas kasus pelanggaran hak asasi manusia. Nuansa khusus ini oleh para ahli disebut sebagai salah satu bentuk khusus dari kejahatan politik (political crimes). Kejahatan politik dapat dibedakan kepada kejahatan melawan penguasa (crimes against the goverment), seperti pemberontakan, demonstrasi ilegal, terorisme, gerakan subversif, dan kejahatan yang dilakukan oleh penguasa (crimes by government, state crimes, political policing, governmental crimes), seperti pelanggaran hukum oleh aparat pemerintah, militer, intelijen. Pelanggaran hak asasi manusia termasuk ke dalam kategori kedua dari kejahatan politik. Pelanggaran hak asasi manusia mempunyai nuansa khusus, yakni penyalahgunaan kekuasaan dalam arti pelaku berbuat dalam konteks pemerintahan dan difasilitasi oleh kekuasaan pemerintah (committed within a govermental context and facilitated by governmental power). Bahkan, dikatakan juga bahwa perbuatan melanggar hak asasi manusia dilakukan dalam kerangka atau disertai asosiasi dengan status pemerintahan (within or in association with governmental status). ${ }^{8}$ Pada kenyataannya, pelanggaran hak asasi manusia umumnya dilakukan oleh aparat negara, terutama militer.

${ }^{8}$ Muladi, "Prospek Pengaturan Pengadilan Hak Asasi Manusia (HAM) di Indonesia," Makalah pada Seminar Nasional Rancangan Undang-Undang Pengadilan HAM (Jakarta, 16 Februari 2000), h. 7. Pembagian tindak pidana politik kepada kejahatan melawan negara/penguasa dan kejahatan oleh penguasa merupakan perkembangan baru dalam hukum pidana. Pada pembagian hukum 
Penggalan terakhir dari definisi di atas, yakni: “...dan tidak mendapatkan atau dikhawatirkan tidak akan memperoleh penyelesaian hukum yang adil dan benar berdasarkan mekanisme hukum yang berlaku", merupakan ciri khas lain dari pelanggaran HAM. Kekhawatiran ini bisa disebabkan oleh kelemahan peraturan perundang-undangan dan bisa juga karena pengaruh pelaku pelanggaran hak asasi manusia. Sebagaimana disinyalir, aparat negara adalah pihak yang paling berpeluang dan paling sering melakukan pelanggaran HAM, sementara mereka memiliki kekuasaan yang dapat diselewengkan untuk mempengaruhi proses dan hasil persidangan.

Di dalam Undang-Undang Nomor 26 tahun 2000 tentang Pengadilan HAM disebutkan bahwa Pengadilan HAM hanya bertugas dan berwenang memeriksa dan memutus perkara pelanggaran hak asasi manusia yang berat (pasal 4), yaitu kejahatan genosida (genocide) dan kejahatan terhadap kemanusiaan (crimes againts humanity) (pasal 7-9). Kejahatan genosida adalah setiap perbuatan yang dilakukan dengan maksud untuk menghancurkan atau memusnahkan seluruh atau sebagian kelompok bangsa, ras, kelompok etnis, kelompok agama, dengan cara membunuh anggota kelompok; mengakibatkan penderitaan fisik atau mental yang berat terhadap anggota-anggota kelompok; menciptakan kondisi kehidupan kelompok yang akan mengakibatkan kemusnahan secara fisik baik seluruh atau sebagiannya; memaksakan tindakan-tindakan yang bertujuan mencegah kelahiran di dalam kelompok; atau memindahkan secara paksa anak-anak dari kelompok tertentu ke kelompok lain (pasal 8).

Sedangkan kejahatan terhadap kemanusiaan adalah salah satu perbuatan yang dilakukan sebagai bagian dari serangan yang meluas atau sistematik yang diketahui bahwa serangan tersebut ditujukan secara langsung terhadap penduduk sipil. Yang dimaksud dengan serangan yang ditujukan secara langsung terhadap penduduk sipil adalah suatu rangkaian perbuatan yang dilakukan terhadap penduduk sipil sebagai kelanjutan kebijakan penguasa atau kebijakan yang berhubungan dengan organisasi. Kejahatan terhadap kemanusiaan dapat berupa pembunuhan; pemusnahan, meliputi perbuatan yang menimbulkan penderitaan yang dilakukan dengan sengaja, antara lain berupa perbuatan menghambat pemasokan barang makanan dan obat-obatan yang dapat menimbulkan pemusnahan pada sebagian penduduk; perbudakan, termasuk perdagangan manusia, khususnya perdagangan wanita dan anak-anak; pengusiran atau pemindahan penduduk secara paksa yaitu pemindahan orang-orang secara paksa dengan cara pengusiran atau tindakan pemaksaan yang lain dari daerah di mana mereka bertempat tinggal secara sah, tanpa didasari alasan yang diizinkan oleh hukum internasional; perampasan kemerdekaan atau perampasan kebebasan fisik lain secara sewenang-wenang yang melanggar (asas-asas) ketentuan pokok hukum internasional; penyiksaan, yakni dengan sengaja dan melawan hukum menimbulkan kesakitan atau penderitaan yang berat, baik fisik maupun mental, terhadap seorang tahanan atau seseorang yang berada di bawah pengawasan; perkosaan, perbudakan seksual, pelacuran secara paksa, pemaksaan kehamilan, pemandulan atau sterilisasi secara paksa atau bentuk-bentuk kekerasan seksual lain yang setara; peng- 
aniayaan terhadap suatu kelompok tertentu atau perkumpulan yang didasari persamaan paham politik, ras, kebangsaan, etnis, budaya, agama, jenis kelamin, atau alasan lain yang telah diakui secara universal sebagai hal yang dilarang menurut hukum internasional; penghilangan orang secara paksa, yakni penangkapan, penahanan, atau penculikan seseorang oleh atau dengan kuasa, dukungan atau persetujuan dari negara atau kebijakan organisasi, diikuti oleh penolakan untuk mengakui perampasan kemerdekaan tersebut atau untuk memberikan informasi tentang nasib atau keberadaan orang tersebut, dengan maksud untuk melepaskan dari perlindungan hukum dalam jangka waktu yang panjang; kejahatan apartheid, yakni perbuatan tidak manusiawi yang dilakukan dalam konteks suatu rezim kelembagaan berupa penindasan dan dominasi oleh suatu kelompok rasial atas kelompok atau kelompok-kelompok ras lain dan dilakukan dengan maksud untuk mempertahankan rezim itu.

Yang harus mendapatkan perhatian khusus dalam genosida dan kejahatan kemanusiaan adalah dua elemen sebagai berikut. Pertama, perbuatan tersebut dilakukan sebagai bagian dari suatu serangan meluas (widespread) dan sistematik (systematic) yang ditujukan kepada penduduk sipil. Kedua, keharusan adanya pengetahuan pelaku bahwa perbuatan yang dilakukan merupakan bagian dari atau dimaksudkan untuk menjadi bagian serangan yang meluas atau sistematik terhadap penduduk sipil. Menurut Muladi, adanya persyaratan pelaku harus memiliki pengetahuan bahwa serangan diarahkan kepada penduduk sipil (knowledge of the attack) harus diartikan sebagai kesengajaan khusus (specific intent). Misalnya, seseorang yang turut serta melakukan kejahatan terhadap kemanusiaan berupa pembunuhan, tetapi dia tidak sadar bahwa perbuatannya merupakan bagian dari suatu serangan meluas atau sistematis terhadap penduduk sipil, maka dia dapat dinyatakan bersalah telah melakukan pembunuhan, tetapi tidak dalam kerangka kejahatan terhadap kemanusiaan. Perlu ditegaskan bahwa untuk dapat dipidana karena melakukan kejahatan terhadap kemanusiaan, tidak disyaratkan pelaku (perpetrator) telah mengetahui karakteristik serangan, rincian pasti (precise details) perencanaan, atau kebijakan negara atau organisasi pelaku kejahatan terhadap kemanusiaan. ${ }^{9}$

Dengan demikian, kasus pelanggaran hak asasi manusia memiliki nuansa khusus dan memenuhi kriteria berikut. Pertama, perbuatan melanggar hak asasi manusia. Kedua, pelanggaran pada umumnya dilakukan aparat negara sehingga terjadi penyalahgunaan

pidana secara konvensional, pembagian seperti itu tidak ditemukan. Tindak pidana politik hanya diarahkan kepada kejahatan melawan negara/pemerintah yang sah. Lihat antara lain: EY. Kanter dan S.R. Sianturi, Asas-Asas Hukum Pidana di Indonesia dan Penerapannya, Cet. 3 (Jakarta: Storia Grafika, 2002), h. 240; Andi Hamzah, Asas-Asas Hukum Pidana, Cet. 2 (Jakarta: Rineka Cipta, 1994), h. 102 dan Wirjono Prodjodikoro, Asas-Asas Hukum Pidana di Indonesia, Cet. 6 (Bandung: Eresco, 1989).

${ }^{9}$ Muladi, "Kejahatan terhadap Kemanusiaan," Makalah disampaikan pada Pelatihan HAM bagi Hakim dan Hakim Ad Hoc di Hotel Santika Jakarta 7 Nopember 2001 (Jakarta: Departemen Kehakiman dan HAM R.I., 2001), h. 3-5. 
kekuasaan di mana pelaku berbuat dalam konteks pemerintahan dan atau difasilitasi oleh kekuasaan pemerintah. Ketiga, dikhawatirkan tidak memperoleh penyelesaian hukum yang adil dan benar karena kekuasaan atau pengaruh pelaku. Keempat, dilakukan sebagai bagian dari suatu serangan meluas atau sistematik yang ditujukan kepada penduduk sipil (kriteria ini khusus untuk pelanggaran hak asasi manusia berat). Pembahasan selanjutnya difokuskan kepada kasus-kasus yang memenuhi kriteria-kriteria kasus pelanggaran hak asasi manusia tersebut.

\section{Kasus-Kasus Pelanggaran HAM}

Dari eksplorasi dan penjelajahan terhadap berbagai kasus yang pernah diangkat ke peradilan Islam pada masa Nabi SAW. dan tercatat di dalam kitab-kitab hadis dan sejarah, ditemukan beberapa kasus yang memenuhi sebagian atau seluruh kriteria kasus pelanggaran hak asasi manusia sebagaimana tersebut di atas. Di antara kasus yang dapat dikategorikan sebagai kasus pelanggaran hak asasi manusia adalah sebagai berikut:

\section{Kasus Zubair bin Awwâm}

Kasus ini adalah persengketaan hak pengairan atau irigasi antara Zubair bin Awwâm dan seorang Ansar. Seorang sahabat dari kalangan Ansar menggugat Zubair kepada Rasulullah SAW. karena Zubair dianggap telah menahan dan merugikan haknya atas air dan pengairan, padahal hak tersebut merupakan hak umum yang mesti dijamin untuk setiap orang. Peristiwa ini termaktub dalam hadis berikut:

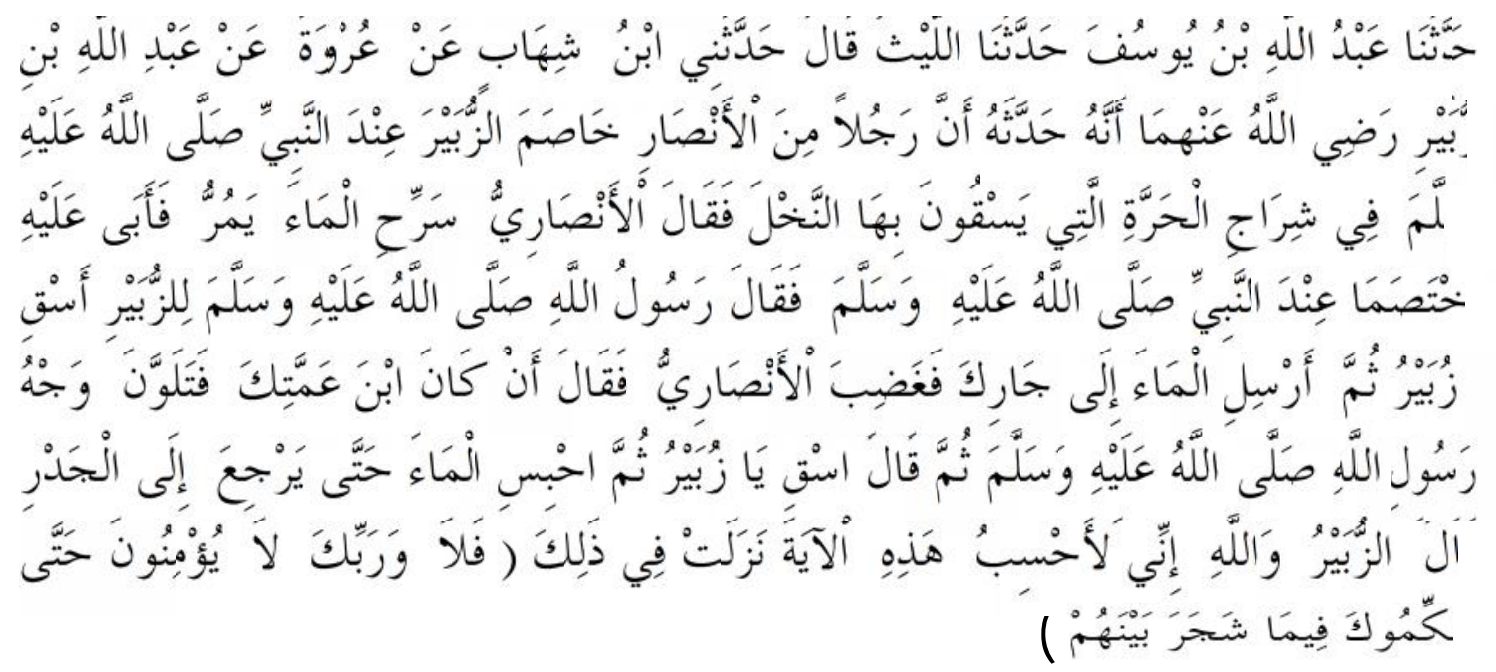

"Hadis yang berasal dari Yûsuf, dari al-Laits, dari Ibn Shihâb, dari 'Urwah, dari 'Abdillâh Ibn Zubair r.a. bahwa sesungguhnya seorang dari golongan Ansar berperkara dengan Zubair di hadapan Rasulullah SAW. mengenai aliran air (irigasi) di Harrah. Orang Ansar tersebut berkata: "Alirkanlah air itu!" Zubair menolak. Mereka lalu bersengketa di hadapan Rasulullah SAW. Rasulullah SAW. bersabda: "Pakailah air itu hai Zubair, lalu alirkan ke tetanggamu!" 
Orang Ansar tersebut marah dan berkata: "Mentang-mentang Zubair anak bibimu." Rona muka Rasulullah SAW. berubah mendengar ucapan tersebut. Lalu beliau bersabda kepada Zubair sekali lagi: "Pakailah air itu hai Zubair, lalu alirkan ke tetanggamu!" Zubair berkata: "Saya menduga ayat ini (Maka demi Tuhanmu, mereka belumlah beriman sehingga mereka menjadikan kamu hakim terhadap perkara yang mereka perselisihkan) turun berkenaan dengan peristiwa tersebut" (H.R. Bukhârî). ${ }^{10}$

Dari segi materi yang dipersengketakan, kasus ini dapat dipandang sebagai pelanggaran hak asasi manusia karena hak atas kebutuhan pokok merupakan bagian dari hak asasi manusia yang mesti diakui dan dihormati. Namun, para ahli masih berbeda pendapat apakah kasus ini memenuhi kriteria dan unsur tindak pelanggaran hak asasi manusia (al-mazhâlim) sebagaimana telah dijelaskan pada pembahasan sebelumnya. Sebagian ahli berpendapat bahwa kasus ini termasuk kasus kezaliman penguasa terhadap rakyat dari sudut pandang bahwa Zubair bin Awwâm adalah kerabat dekat Nabi SAW. yang merupakan penguasa ketika itu. Zubair adalah anak dari Shafiyah binti 'Abdul Muthalib, bibi kandung Nabi SAW. Dari garis ayah, silsilah Zubair bertemu pula dengan silsilah Nabi SAW. pada kakek mereka Qusay bin Kilab. ${ }^{11}$ Dengan demikian, terdapat salah satu unsur dan kriteria tindakan pelanggaran hak asasi manusia, yakni pelaku tindak pelanggaran hak asasi manusia adalah orang yang memiliki kekuasaan atau pengaruh, baik karena memiliki sendiri kekuasaan tersebut maupun sebagai efek dari hubungan dekat dengan penguasa. Realitas ini menyebabkan terpenuhi unsur atau kriteria lain dari tindak pelanggaran hak asasi manusia, yakni adanya kekhawatiran kasus tersebut tidak dapat diselesaikan secara adil karena pengaruh dan kekuasaan pelaku bisa mempengaruhi proses dan keputusan yang dihasilkan oleh pengadilan yang mengadili kasus tersebut. Sementara itu, sebagian ahli yang lain mengisyaratkan bahwa kasus ini bukan tindak pelanggaran hak asasi manusia sebab Zubair bin Awwâm bukanlah penguasa dan bukan pula kerabat dekat seorang penguasa. ${ }^{12}$ Dengan demikian, dia tidak memiliki cukup pengaruh untuk mempengaruhi proses dan hasil persidangan di pengadilan.

Terlepas dari perbedaan pandangan di atas, secara faktual kasus ini memenuhi sebagian dari kriteria tindak pelanggaran hak asasi manusia. Pertama, obyek sengketa adalah hak pengairan yang termasuk ke dalam kelompok hak-hak umum yang dimiliki setiap orang dan mesti dilindungi. Dalam konteks kasus ini, sahabat dari kalangan Ansar merasa haknya atas pengairan tidak terpenuhi dan terlindungi, dihalangi oleh Zubair yang kebetulan memiliki kebun di bagian atas atau bagian hulu dari kebunnya. Kedua, kekhawatiran adanya intervensi

${ }^{10}$ Muhammad bin Ismâ'îl Abû 'Abdillâh al-Bukhârî, Shahîh al- Bukhârî, Cet. 3, juz II (Beirût: Dâr Ibn Katsîr, 1987), h. 832

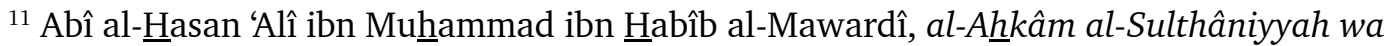
al-Wilâyah al-Dîniyyah (Beirût: Dâr al-Fikr, 1380 H/1960 M), h. 75.

${ }^{12}$ Nâshir ibn 'Âqil ibn Jâbir al-Thârifî, al-Qadhâ' fì 'Âhdi 'Umar ibn al-Khaththâb (Jeddah: Dâr al-Madanî, 1986), h. 563. 
dan pengaruh kekuasaan dalam kasus ini demikian jelas mengingat hubungan kekeluargaan antara Zubair dan Nabi SAW. yang akan mengadili kasus tersebut. Kekhawatiran tersebut secara gamblang diungkapkan sendiri oleh sahabat Ansar ketika mendengar keputusan Nabi SAW. yang belum memenuhi keinginannya, ia berkata kepada Nabi SAW.: "Mentangmentang Zubair anak bibimu". Ucapan tersebut mengindikasikan kecurigaan dan kekhawatiran sahabat dari kalangan Ansar tersebut bahwa Nabi SAW. telah mengeluarkan keputusan yang memihak dan tidak adil, walaupun sesungguhnya Nabi SAW. telah berlaku adil dan memberikan keputusan yang benar.

Meskipun kasus ini mengandung muatan pelanggaran hak asasi manusia dan memenuhi beberapa kriteria tindak pelanggaran hak asasi manusia, tetapi belum dapat menggambarkan suatu proses penyelesaian kasus hak asasi manusia secara lengkap, luas, dan menyeluruh. Hal ini karena sifat kasusnya yang kecil, hanya melibatkan dua individu, dan pokok masalah yang tidak kompleks dan tidak terlalu penting. Contoh-contoh kasus berikut dapat mewakili bagaimana penyelesaian kasus pelanggaran hak asasi manusia dalam sejarah peradilan Islam.

\section{Kasus Khâlid ibn al-Walîd}

Masalah pokok pada kasus ini adalah tindakan pembunuhan, penganiayaan, dan kezaliman lainnya yang dilakukan oleh Khâlid bin Walîd dan pasukannya terhadap penduduk Bani Jadzîmah yang jelas-jelas melanggar bagian terpenting dari hak asasi manusia. Peristiwa ini dapat dirujuk antara lain pada hadis berikut.

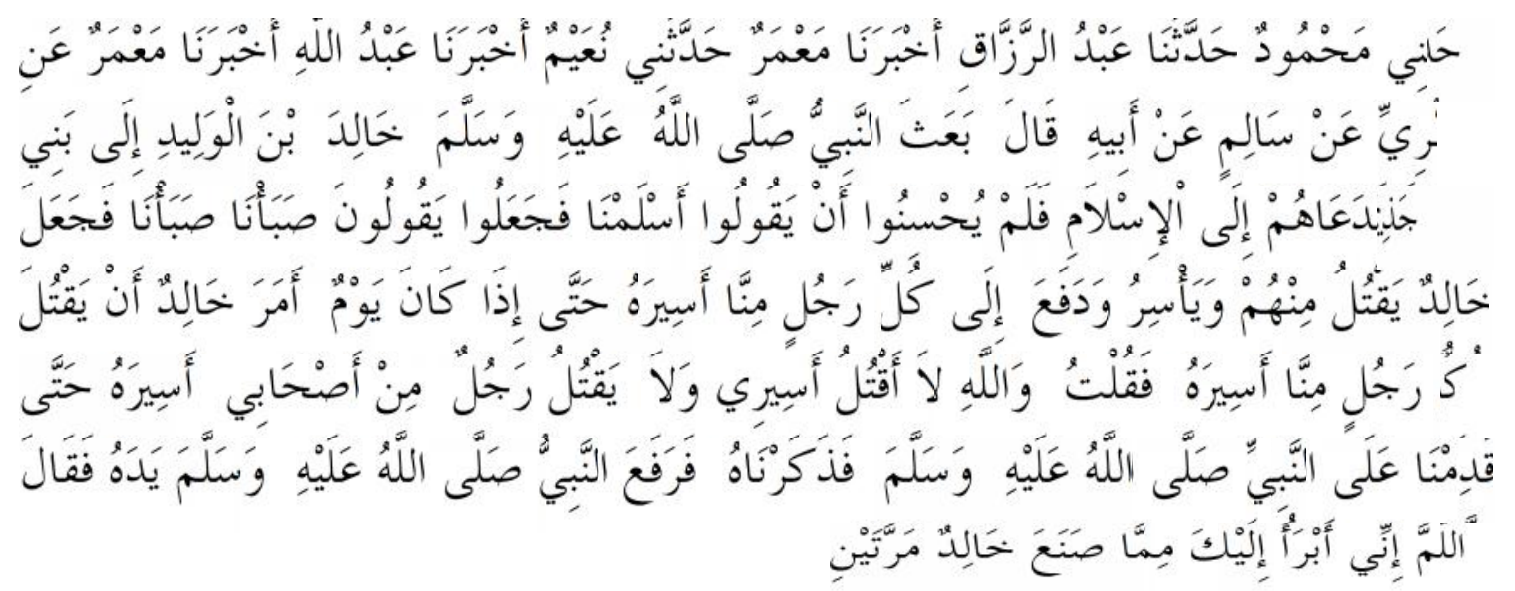

"Hadis diterima dari Mahmûd, dari 'Abd al-Razzâq, dari Ma'mar. Disampaikan juga dari Nu'aim, dari 'Abdillâh, dari Ma'mar, dari al-Zuhrî, dari Sâlim, dari bapaknya yang berkata bahwa Nabi SAW. mengutus Khâlid bin al-Walîd kepada Bani Jadzîmah dan Khâlid lalu mendakwahi mereka untuk memeluk Islam. Orang-orang Jadzîmah belum biasa mengucapkan "aslamna" (kami telah masuk Islam), lalu mereka menjadikan ungkapan "shaba'na, shaba'na" sebagai gantinya. (Mendengar ungkapan tersebut) Khâlid membunuh sebagian mereka, menawan, dan membagikan tawanan kepada masing-masing pasukan Islam. Berselang sehari, Khâlidmemerintahkan 
pasukan Islam membunuh tawanan mereka masing-masing. Maka saya (ayah Sâlim) berkata: "Demi Allah, saya tidak akan membunuh tawanan saya dan sahabat-sahabat saya juga tidak akan membunuh tawanan mereka." Sampai kami menemui Nabi SAW. dan menyampaikan peristiwa tersebut. Lalu Nabi SAW. mengangkat kedua tangannya sambil berdoa, "Ya Allah, aku berlepas tangan kepada-Mu atas apa yang diperbuat Khâlid." Ungkapan tersebut diulangi

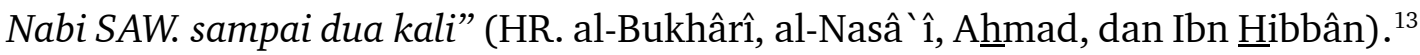

Kasus Khâlid berawal dari kebijakan Nabi SAW. setelah pembebasan kota Mekkah untuk mengirim beberapa detasemen ke berbagai penjuru jazirah Arab untuk misi dakwah, bukan dalam rangka operasi militer. Di antaranya adalah satu detasemen di bawah pimpinan Khâlid ibn Walîd yang dikirim ke wilayah Tihamah bawah, daerah yang dihuni antara lain oleh Bani Jadzîmah. Ketika kabilah Bani Jadzîmah melihat kedatangan detasemen pimpinan Khâlid bin Walîd, mereka langsung bersiaga dan menyiapkan senjata untuk mempertahankan diri. Melihat gelagat demikian, Khâlid berkata: "Letakkan senjata kalian! Orang banyak telah memeluk Islam." Jahdam, salah seorang Bani Jadzîmah, mengingatkan kaumnya: "Celakalah kalian hai Bani Jadzîmah! Orang ini adalah Khâlid!” Demi Allah, jika kalian meletakkan senjata, pasti dia menawan dan membunuh kalian. Demi Allah, Aku tidak akan pernah meletakkan senjata." Beberapa orang kabilah Bani Jadzîmah memegangi Jahdam dan melucuti senjatanya sambil berkata: "Hai Jahdam, apakah kamu ingin menumpahkan darah kami? Sungguh orang banyak telah masuk Islam, meletakkan senjata, menghentikan perang, dan hidup aman". Ketika kabilah Bani Jadzîmah telah meletakkan senjata, atas perintah Khâlid, tangan mereka diikat ke belakang pundak. Khâlid kemudian menghunuskan pedangnya kepada mereka sehingga ada yang terbunuh. Salah seorang Bani Jadzîmah berhasil meloloskan diri dan melaporkan kejadian tersebut kepada Rasulullah SAW. di Madinah. Nabi SAW. langsung melakukan penyelidikan dan bertanya kepada orang yang melaporkan, "Adakah orang yang menentang tindakan Khâlid tersebut?” Orang tersebut menjawab: "Ya, seorangyang berkulit putih dan bertinggi badan sedang, tapi orang itu kemudian diam setelah dihardik oleh Khâlid. Tindakan Khâlid juga ditentang oleh orang yang berbadan tinggi kurus. Silahkan cek kepada keduanya". Setelah diselidiki diketahui bahwa yang menentang tindakan Khâlid tersebut adalah 'Abdullah bin 'Umar bin Khathab dan Sâlim bekas budak Abû Hudzaifah. ${ }^{14}$

${ }^{13}$ Al-Bukhârî, Shahîh al-Bukhârî, juz IV, h. 1577. Hadis yang sama atau hampir sama dapat ditemukan didalam Shahîh al-Bukhârî, juz VI, h. 2628; Al-Nasâ‘î, Sunan al-Nasấî̀, juz VIII (Halb: Maktab al-Mathbû'ât al-Islamiyyah, 1406 H/1986 M), h. 236; Ahmad ibn Hanbal, Musnad Ahmad

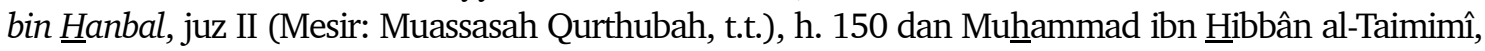
Shahîh Ibn Hibbân, juz XI, Cet. 2, (Beirût: Mu'assasah al-Risâlah, 1414 H/1993 M), h. 53. Pemaparan lebih lengkap kasus Khâlid dapat dilihat pada: 'Abd al-Malik Ibn Hisyâm, al-Sîrah al-Nabawiyyah, Tahqị̂q Thâhâ 'Abd al-Raûf Sa'îd, juz. V, Cet. 1 (Beirût: Dâr al-Jail, 1411), h. 93-102.

${ }^{14}$ Ibn Hisyâm, al-Sîrah al-Nabawiyyah, juz. V, h. 93-96 dan Ibn Hajar Al-Asqalânî, Fath alBârî bi Syarh Shahîh al-Bukhârî, Tahqîq Muhammad Fu'ad 'Abd al-Bâqî, juz VIII (Beirût: Dâr alMa'rifah, t.t.), h. 58 
Setelah memastikan adanya peristiwa tersebut, Nabi SAW. memanggil 'Alî bin Abi Thâlib dan bersabda: "Hai 'Alî, pergilah ke Bani Jadzîmah! Teliti dengan seksama kasus mereka dan adili perbuatan jahiliyah ini di bawah wewenangmu!." 'Alî r.a. lalu berangkat dengan membawa banyak harta yang diberikan Nabi SAW. 'Alîmengadili kasus tersebut dan memutuskan memberikan diyat (denda) atas setiap kerugian darah (nyawa) dan harta Bani Jadzîmah sehingga harta yang dibawanya hanya tersisa sedikit. Lalu 'Alî bertanya: "Hai Bani Jadzîmah, masih adakah darah dan harta yang belum dibayar diyatnya?" Mereka menjawab: "Tidak ada." 'Alî lalu berkata: "Sisa harta ini aku berikan kepada kalian sebagai bentuk kehati-hatian Rasulullah SAW. atas apa yang beliau tidak ketahui dan kalian juga tidak mengetahuinya." "Alî kemudian pulang ke Madinah dan melaporkan tugasnya kepada Rasulullah SAW. Nabi SAW bersabda: "Engkau telah bertindak tepat dan baik." Setelah itu Nabi SAW. berdiri menghadap kiblat, menengadahkan kedua tangan sehingga kelihatan ketiaknya, dan berdoa: "Ya Allah, aku berlepas tangan kepada-Mu atas apa yang diperbuat Khâlid bin Walîd." Ungkapan tersebut diulangi Nabi SAW. sampai dua kali. ${ }^{15}$

Kasus Khâlid bin Walîd ini dapat dan tepat disebut sebagai contoh kasus tindak pidana pelanggaran hak asasi manusia, termasuk jika ditinjau dari kaca mata hukum dan peraturan perundang-undangan yang berlaku sekarang sekalipun. Beberapa unsur dan kriteria utama pelanggaran hak asasi manusia telah terpenuhi pada kasus ini.

Pertama, adanya perbuatan pidana yang dilakukan secara sengaja dan melanggar hak asasi manusia. Dalam konteks kasus ini, hak asasi yang dilanggar adalah hak yang berkaitan dengan jiwa dan harta karena telah terjadi pembunuhan dan perampasan atau perusakan harta secara semena-mena.

Kedua, perbuatan pidana dilakukan oleh seorang atau sekelompok orang yang berstatus sebagai aparat negara. Sebagaimana dijelaskan sebelumnya, aparat negara disebut secara khusus di dalam definisi tindak pelanggaran hak asasi manusia karena mereka, secara faktual, merupakan pihak yang sering terlibat dalam berbagai tindak pelanggaran hak asasi manusia. Pada kasus di atas, pelakunya adalah Khâlid dan pasukannya yang notabene adalah aparat pemerintah karena sedang mengemban mandat dan tugas khusus dari Nabi SAW., kepala negara dan kepala pemerintahan Islam ketika itu. Jadi, pada peristiwa tersebut telah terjadi penyalahgunaan kekuasaan dalam arti pelaku berbuat kejahatan dalam konteks pemerintahan dan menggunakan fasilitas kekuasaan pemerintah (committed within a govermental context and facilitated by governmental power). Dengan demikian, kasus ini dapat digolongkan al-mazhâlim dalam hukum Islam atau apa yang disebut para ahli hukum umum sebagai kejahatan yang dilakukan oleh penguasa (crimes by goverment, state crimes, political policing, govermental crimes) dan merupakan salah satu bentuk dari kejahatan politik. Kasus Khâlid, dengan melihat kedudukannya sebagai panglima perang, h. 58

${ }^{15}$ Ibn Hisyâm, al-Sîrah al-Nabawiyyah, juz. V, h. 96 dan al-Asqalânî, Fath al-Bârî, juz VIII, 
juga memperkuat anggapan dan kecenderungan umum bahwa aparat militer merupakan pihak yang paling banyak terlibat dalam pelanggaran hak asasi manusia.

Ketiga, kasus Khâlid tersebut tidak mendapatkan atau dikhawatirkan tidak memperoleh penyelesaian hukum yang adil dan benar karena pelaku pelanggaran hak asasi manusia memiliki kekuasaan yang dapat mempengaruhi proses dan hasil persidangan. Pada kasus di atas, kekhawatiran tidak adanya penyelesaian hukum yang adil bisa terjadi jika kasus tersebut hanya diselesaikan melalui pengadilan khusus dalam internal detasemen pimpinan Khâlid bin Walîd karena adanya pengaruh kuat Khâlid sebagai pimpinan detasemen. Kekhawatiran tersebut juga masih ada, minimal pada diri korban, jika kasus diselesaikan melalui mekanisme hukum dan pengadilan biasa mengingat besarnya pengaruh dan kekuasaan yang dimiliki Khâlid sebagai salah seorang panglima pasukan Islam ternama, meskipun kekhawatiran semacam itu terlalu berlebihan mengingat keluhuran budi pekerti Nabi SAW. dan para sahabat ketika itu yang tidak mungkin berlaku zalim hanya karena membela sahabat yang bersalah.

Keempat, kasus Khâlid dapat dikelompokkan sebagai pelanggaran hak asasi manusia yang berat mengingat tindakan tersebut dilakukan secara sadar terhadap penduduk sipil dan telah memenuhi kriteria bersifat meluas dan sistematis. Sebagaimana dijelaskan sebelumnya, pelanggaran hak asasi manusia berat memiliki ciri khas yaitu suatu serangan bersifat meluas dan sistematik yang ditujukan kepada penduduk sipil. Di samping itu, harus ada pengetahuan pelaku bahwa perbuatan yang dilakukan merupakan bagian dari atau dimaksudkan untuk menjadi bagian serangan yang meluas atau sistematik terhadap penduduk sipil. ${ }^{16}$ Tindak pelanggaran hak asasi manusia yang dilakukan Khâlid dan pasukannya jelas bersifat meluas karena sasarannya adalah seluruh warga Bani Jadzîmah, kecuali wanita, anak-anak, dan orang tua. Perbuatan tersebut juga dilakukan secara sistematis, dalam makna dilaksanakan secara terencana dan teratur. Khâlid dan pasukannya juga menyadari bahwa sebagian besar warga Bani Jadzîmah berstatus sipil, bukan kombatan yang boleh diperangi. Meskipun sebagian ada yang berupaya mengangkat senjata, tetapi akhirnya mereka meletakkan senjata setelah diperintahkan Khâlid dan dibujuk sebagian warga Bani Jadzîmah.

Rasulullah SAW. memberikan respon yang cepat dan tepat terhadap kasus Khâlid bin Walîd tersebut. Nabi SAW. langsung membentuk tim khusus, yaitu 'Alî bin Abî Thâlib dan para pembantunya, yang diberikan kewenangan besar dan luas untuk mengambil langkah-langkah yang diperlukan dalam rangka penyelesaian kasus. Langkah pertama yang dilaksanakan adalah melakukan upaya-upaya investigasi (penyelidikan dan penyidikan) yang dapat dilihat dari tindakan Nabi SAW. untuk mengorek keterangan dari pelapor dan melakukan cek silang dengan para saksi lain yang melihat langsung peristiwa. Nabi SAW. juga menasehati 'Alî untuk meneliti kasus tersebut secara seksama sebelum mengadili dan

\footnotetext{
${ }^{16}$ Muladi, "Kejahatan terhadap Kemanusiaan," h. 3.
} 
mengambil keputusan. Tindakan investigasi sangat diperlukan agar fakta-fakta yang berkaitan dengan peristiwa dapat terungkap secara jernih dan maksimal. Berdasarkan faktafakta tersebut, tindakan-tindakan selanjutnya dapat diambil secara tepat, objektif, dan bijaksana.

Langkah kedua yang dilakukan adalah mengungkapkan kasus secara objektif, teliti, adil, dan bijaksana. Tugas pengungkapan kebenaran tersebut diserahkan Nabi SAW. kepada 'Alî, seorang sahabat yang terkenal cerdas, jujur, adil, dan berani. Dengan kualitas dan kapasitas yang dimilikinya, 'Alî berhasil mengungkapkan kasus secara transparan, objektif, jujur, dan adil yang dapat dibuktikan dengan diterimanya keputusan yang ditetapkan secara baik oleh berbagai pihak. Nabi SAW. sendiri tidak segan-segan memberikan pujian terhadap hasil kerja 'Alî tersebut.

Langkah ketiga yang diambil adalah melakukan upaya-upaya rekonsiliasi. Inti dari rekonsiliasi adalah pengakuan kesalahan, pemaafan, dan upaya menetralisir dampak negatif kasus yang terjadi melalui upaya perdamaian, rehabilitasi, kompensasi, dan sebagainya. Rekonsiliasi sangat dibutuhkan karena tidak mungkin seluruh kasus dan aspek pelanggaran hak asasi manusia bisa terselesaikan lewat mekanisme pengadilan semata, apalagi pada kasus-kasus yang sulit dan komplit. Pengadilan juga tidak bisa secara maksimal menyembuhkan semua duka batin dan luka sosial yang timbul sebagai dampak negatif dari peristiwa tindak pelanggaran hak asasi manusia. Dalam konteks ini, rekonsiliasi merupakan mekanisme alternatif dan komplementer bagi pengadilan untuk menyelesaikan kasus pelanggaran hak asasi manusia secara lebih komprehensif.

Upaya rekonsiliasi pada kasus Khâlid bin Walîd terlihat jelas pada upaya Nabi Muhammad SAW. dan 'Alî mengungkapkan secara jernih dan terbuka semua fakta dan kebenaran sekitar peristiwa pelanggaran berat hak asasi manusia tersebut. Nuansa rekonsiliasi juga terlihat jelas pada keputusan pengadilan yang dihasilkan, yakni penerapan sanksi hukum berupa denda darah dan ganti rugi harta. Upaya rekonsiliasi semakin kentara ketika 'Alî memberikan kelebihan harta dari sisa pembayaran diat dan ganti rugi kepada warga Bani Jadzîmah sebagai bentuk perwujudan sikap hati-hati (ihtiyâth). Pemberian kelebihan harta memang dinyatakan Alî sebagai bentuk kehati-hatian (ihtiyâth) agar tidak ada denda atau ganti rugi yang terluputkan karena keterbatasan informasi, tetapi pada sisi lain pemberian itu dapat pula dipandang sebagai bentuk kompensasi agar pihak-pihak yang dirugikan lebih mudah memaafkan, menghapuskan dendam, dan melupakan peristiwa pahityang telah terjadi.

Dengan demikian, kasus Khâlid bin Wâlid dan pasukannya telah menggambarkan secara relatif lebih utuh dan lengkap bagaimana kebijakan dan mekanisme penyelesaian kasus pelanggaran hak asasi manusia, termasuk pelanggaran hak asasi manusia berat, pada sistem peradilan Islam di masa Nabi SAW. Kasus ini, pada kadar dan tingkatan tertentu, bisa dijadikan contoh dan yurisprudensi bagi penyelesaian kasus-kasus pelanggaran hak asasi manusia, termasuk oleh lembaga-lembaga yang berwenang dewasa ini. 
Ikhwan: Penyelesaian Kasus Pelanggaran HAM Pada Masa Rasulullah SAW.

\section{Kasus Sawad bin Ghaziyyah}

Rasulullah SAW. tidak hanya menjalankan pengadilan untuk kasus-kasus pelanggaran hak asasi manusia yang besar dan penting saja, tetapi juga menyelesaikan kasus-kasus pelanggaran hak asasi yang sifatnya kecil, seperti kasus Sawad bin Ghaziyyah. Ketika perang Badar, Rasulullah meluruskan barisan para sahabatnya, sementara tangan Rasulullah memegang tombak yang memberi isyarat lurus kepada mereka. Ketika melewati Sawad bin Ghaziyyah yang agak menonjol ke luar barisan, Rasulullah menusukkan tombak yang ada di tangannya (tanpa melukai) ke perut Sawad seraya memberi perintah: "Luruskan barisanmu, hai Sawad." Sawad menjawab: "Wahai Rasulullah, engkau telah menyakitiku, padahal engkau diutus dengan membawa kebenaran dan keadilan. Aku mesti menuntut qishâsh kepadamu." Rasulullah lalu membuka pakaian sehingga terlihat perutnya, dan bersabda: "Silakan, balaslah aku!" Melihat hal itu, Sawad lalu memeluk dan mencium perut Rasulullah SAW. ${ }^{17}$

Kasus Sawad di atas dapat saja dipandang tidak terlalu berarti sebagai yurisprudensi mengingat unsur material (al-rukn al-mâdî) yang hanya berupa kasus pemukulan. Namun, pada kasus tersebut terdapat beberapa unsur yang memenuhi kriteria tindak pelanggaran hak asasi manusia di samping mengandung beberapa pelajaran berharga yang penting bagi penghormatan dan penegakan hak asasi manusia. Pada kasus tersebut terdapat unsur pelanggaran hak asasi manusia, meskipun hanya dalam bentuk yang ringan dan tidak membahayakan. Memukul orang tanpa hak dan alasan yang dibenarkan dapat dikategorikan sebagai pelanggaran terhadap hak pemeliharaan diri/jiwa (hifz al-nafs) dalam tingkatan tahsinî (tingkat pelengkap dan penyempurna). Dengan demikian, orang yang merasa teraniaya dan dirugikan berhak untuk menuntut keadilan dan penjatuhan hukuman kepada pelaku pemukulan. Dari sisi unsur moral (al-rukn al-adabî), kasus ini juga memenuhi kriteria tindak pelanggaran hak asasi manusia mengingat pelaku kasus pemukulan adalah aparat negara, dalam hal ini Rasulullah SAW. sendiri yang berkedudukan sebagai kepala negara dan panglima pasukan Islam ketika itu.

Kasus Sawad di atas memberikan gambaran betapa Islam menghormati dan melindungi hak asasi manusia. Sekecil apapun pelanggaran hak asasi manusia yang terjadi, layak mendapat perhatian dan penyelesaian yang semestinya. Kasus tersebut juga menunjukkan nilai-nilai persamaan di dalam Islam bahwa setiap orang memiliki hak dan kedudukan yang sama di hadapan hukum dan proses peradilan.

Masih banyak kasus lain yang bernuansa pelanggaran hak asasi manusia pernah terjadi dan diselesaikan oleh Nabi SAW. Misalnya Nabi SAW. pernah memecat al-AAla' ibn al-Hadramî, pejabat negara yang bertugas di Bahrain, setelah Nabi SAW. menerima informasi yang dapat dipercaya dari 'Abd al-Qaits tentang penyelewengan kekuasaan yang dilakukan

${ }^{17}$ Ibn Hisyam, al-Sirah al-Nabawiyah, juz III, h. 174. 
al-'Ala'. Sebagai gantinya, Nabi SAW. mengangkat Abban ibn Sa'id. ${ }^{18}$ Kasus-kasus yang dipaparkan di atas dipandang cukup mewakili untuk menggambarkan bagaimana metode dan mekanisme penyelesaian kasus-kasus pelangggan hak asasi manusia pada masa Nabi SAW.

\section{Format dan Mekanisme Penyelesaian Kasus Pelanggaran HAM}

Undang-Undang Nomor 26 Tahun 2000 tentang Pengadilan HAM menyediakan tiga mekanisme penyelesaian kasus pelanggaran hak asasi manusia yang berat, yakni melalui Pengadilan Hak Asasi Manusia, melalui Pengadilan Hak Asasi Manusia Ad Hoc, dan melalui Komisi Kebenaran dan Rekonsiliasi. Masing-masing mekanisme diperuntukkan dan disesuaikan dengan karakteristik kasus yang terjadi. Kasus yang terjadi setelah terbentuknya Pengadilan Hak Asasi Manusia diselesaikan oleh Pengadilan Hak Asasi Manusia sesuai dengan tempat kedudukannya. Sedangkan kasus yang terjadi sebelum terbentuk Pengadilan Hak Asasi Manusia dapat diperiksa dan diputus oleh Pengadilan Hak Asasi Manusia Ad Hoc atau menempuh mekanisme perdamaian dan rekonsiliasi melalui Komisi Kebenaran dan Rekonsiliasi. Format dan mekanisme penyelesaian kasus pelanggaran HAM ini akan dilihat relevansinya dengan yang ada di dalam hukum Islam.

Dari contoh kasus dan analisis yang telah dikemukakan di atas, dapat diketahui bahwa sesungguhnya kasus-kasus yang memenuhi sebagian atau seluruh kriteria pelanggaran hak asasi manusia sebagaimana diatur hukum Indonesia telah terjadi sejak masa awal Islam. Kasus-kasus tersebut dilakukan oleh aparat pemerintah atau kerabatnya dan secara khusus banyak melibatkan kalangan militer sebagaimana kecenderungan umum pada kasus-kasus pelanggaran hak asasi manusia dewasa ini. Oleh sebab itu, penanganan kasus cukup sulit karena para pelaku memiliki kekuasaan dan pengaruh yang dapat mempengaruhi proses dan hasil pengadilan.

Para pemimpin Islam, sejak masa Nabi SAW., telah berupaya menyelesaikan kasuskasus pelanggaran hak asasi manusia dengan baik dan adil. Dari contoh kasus yang dipaparkan di atas, dapat diketahui bahwa penyelesaian perkara pelanggaran hak asasi manusia pada peradilan Islam dilakukan dengan tiga metode atau mekanisme.

Pertama, melalui proses berperkara di pengadilan yang diakhiri dengan keputusan hakim. Metode ini terlihat pada kebanyakan contoh kasus, seperti kasus Zubair bin Awwâm. Meskipun lembaga dan mekanisme yang dijalankan belum sempurna seperti pada peradilan moderen, tetapi prosedur penyelesaian perkaranya dapat diurut dan dikonstruksikan kembali. Proses perkara biasanya dimulai dari pengaduan, tuntutan, atau gugatan dari pihak korban. Kemudian dilanjutkan dengan penyelidikan, penyidikan, dan pemeriksaan perkara, meskipun ketiga proses itu terkadang sulit dibedakan dan dipisahkan. Selanjutnya, hakim mengadili

\footnotetext{
${ }^{18}$ Muhhammad 'Abd al-Rahmmân al-Bakr, al-Sulthah al-Qadhâ'iyyah wa al-Syakhshiyyah alQâdhî, (t.tp.: al-Zahrâ' li al-A'lam al-'Arabî, 1408/1988), h.526.
} 
dan memberikan putusan berdasarkan fakta-fakta yang terungkap di dalam persidangan untuk kemudian dilaksanakan (eksekusi).

Metode yang pertama ini, pada prinsipnya, sama dengan penyelesaian kasus pelanggaran hak asasi manusia di Pengadilan Hak Asasi Manusia di Indonesia, baik yang bersifat permanen maupun Ad-Hoc. Perbedaannya hanya terletak pada badan pelaksana dan aspek teknis, dan itu wajar karena perbedaan zaman dan sistem hukum.

Kedua, melalui mekanisme berperkara biasa yang diakhiri ishlâh (rekonsiliasi, perdamaian) di antara para pihak sebelum hakim menjatuhkan putusan. Metode seperti ini terlihat pada kasus Sawad bin Ghaziyyah. Metode kedua ini memiliki kesamaan dengan yang dipakai oleh Pengadilan Hak Asasi Manusia Indonesia, khususnya dalam masalah perdata. Sebagaimana diatur pasal 35 Undang-Undang Nomor 26 Tahun 2000, korban pelanggaran hak asasi manusia dapat memperoleh kompensasi, restitusi, dan rehabilitasi. Dalam putusan Pengadilan Hak Asasi Manusia Ad Hoc Jakarta Pusat tanggal 20 Agustus 2004, Majelis yang diketuai Andi Samsan Nganro, menetapkan bahwa korban pelanggaran hak asasi manusia berat Tanjungpriok berhak mendapat kompensasi. Kompensasi Rp 1,015 miliar diberikan kepada 13 korban ataupun ahli waris korban. ${ }^{19}$ Perbedaannya, Pengadilan Hak Asasi Manusia Indonesia hanya bisa menerapkan metode ini pada tataran perdata, tidak bisa pada masalah pidana. Sementara hukum Islam dapat juga menerapkan metode ini pada kasus pidana yang menyangkut hak perorangan, seperti perkara qishâsh-diyat.

Ketiga, melalui pengungkapan kebenaran dan perdamaian (ishlâh $)$, tanpa melalui proses berperkara di pengadilan. Metode ini diterapkan pada kasus Khâlid bin Walîd sebagaimana terlihat dari langkah dan proses yang ditempuh, yakni investigasi, pengungkapan faktafakta sekitar kasus secara obyektif dan transparan, upaya mewujudkan perdamaian, yang kemudian dilanjutkan dengan pembayaran diyat dan pemberian kompensasi. Sebagaimana metode kedua, metode ini hanya dapat dipakai pada perkara yang menyangkut hak perorangan dan perkara perdata.

Metode ketiga ini tidak ada padanannya pada Pengadilan Hak Asasi Manusia Indonesia, tetapi dapat dikatakan sama dengan metode penyelesaian perkara pelanggaran hak asasi manusia pada Komisi Kebenaran dan Rekonsiliasi (KKR) yang khusus diperuntukkan bagi kasus yang terjadi sebelum pemberlakuan Undang-Undang Nomor 26 Tahun 2000 tentang Pengadilan Hak Asasi Manusia.

Dari berbagai metode penyelesaian kasus pelanggaran hak asasi manusia yang dipakai di dalam sejarah peradilan Islam, metode ishlâh (rekonsiliasi,perdamaian) memiliki tempat istimewa. Metode ini cukup sering digunakan, bahkan pada kasus pelanggaran hak asasi

${ }^{19}$ Awalnya, permohonan kompensasi diajukan juga oleh 85 orang korban Tanjungpriok lewat Yayasan Penerus Bangsa pimpinan Syarifuddin Rambe, tetapi ditolak karena telah melakukan islah dengan pihak TNI yang diwakili Try Sutrisno. Mereka telah menerima uang, beasiswa, dan truk saat islah tahun 2001. Hukum Online.Com "Majlis Kabulkan Pemberian Kompensasi Korban Tanjung Priok," Jakarta, 21 Agustus 2004. 
manusia yang berat, seperti kasus Khâlid bin Walîd. Metode ini terbukti cukup berhasil menyelesaikan perkara secara lebih baik dan menyeluruh. Oleh sebab itu, tidak mengherankan jika perdamaian mendapat apresiasi yang sangat positif di dalam hukum Islam.

Ishlâh atau shulhu secara bahasa berarti memutuskan atau menyelesaikan sengketa. Sedangkan secara istilah, ishlâh bermakna perjanjian untuk mengakhiri permusuhan antara pihak-pihak bersengketa. ${ }^{20}$ Karena sifatnya positif dan bermanfaat, ishlâh sangat dipuji dan dianjurkan oleh Islam dalam berbagai bidang kehidupan, seperti firman Allah di dalam Q.S. al-Baqarah/2: 228: “... Dan suaminya berhak merujuki (isteri)-nya dalam masa menanti itu jika mereka (para suami) itu menghendaki ishlah.....". Pada ayat ini, rujuk disebut ishlâh karena menghilangkan kerusakan hubungan rumah tangga akibat perceraian. Ishlâh juga dianjurkan di dalam kehidupan bermasyarakat dan bernegara, sebagaimana firman Allah di dalam Q.S. al-Hujarât/49: 9: "Dan jika ada dua golongan dari orang-orang mukmin berperang maka damaikanlah (ishlâh) antara keduanya....".

Hukum Islam membolehkan penyelesaian perkara melalui ishlâh asalkan pada perkara yang dibolehkan, memenuhi kriteria keadilan, tidak bertentangan dengan syara', dan dapat diterima semua pihak. Ishlâh semacam ini dinamakan ishlâh yang adil. Sedangkan ishlâh yang bertentangan dengan ketentuan syara', seperti menghalalkan yang haram, mengharamkan yang halal, meninggalkan yang wajib, menzalimi pihak yang lemah, tidak dibenarkan dan ditolak oleh hukum Islam. Ishlâh kategori kedua ini disebut ishlâh mardûd. ${ }^{21}$ Penyelesaian perkara melalui ishlâh hanya boleh dilakukan pada perkara hak manusia (perorangan), ${ }^{22}$ seperti tindak pidana qishâsh-diyat dan pekara perdata, sebab masalah-masalah tersebut merupakan perwujudan hak perorangan. Ishlâh tidak boleh dilakukan pada wilayah hak Allah atau masyarakat, seperti pada perkara hudûd. Dasar hukum kebolehan penyelesaian perkara qishâh $\underline{h}$-diyat melalui ishlâh $\underline{h}$ antara lain sebagai berikut. Allah berfirman di dalam Q.S. al-Baqarah/2: 178:

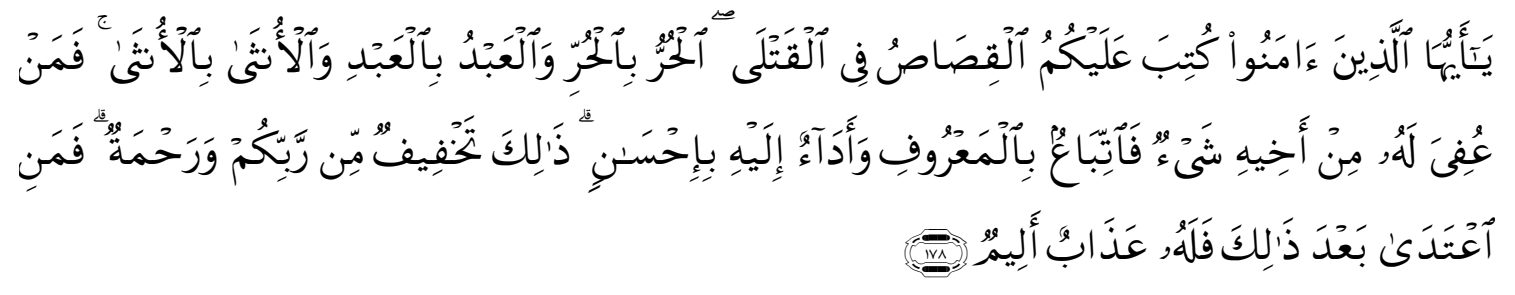

${ }^{20}$ Al-Sayyid Sâbiq, Fiqh al-Sunnah (Beirût: Dâr al-Fikr, 1403/1983), h. 305 dan Badr alDîn Syaddad, Dalâil al-Ahkkâm, juz III (Beirût: Dâr al-Kutub al-'Ilmiyyah, 1991), h. 147.

${ }^{21}$ Ibn Qudamah al-Maqdisî, al-Mughnî, (Beirût: Dâr al-Kutub al-'Ilmiyyah, 1994), h. 177.

${ }^{22}$ Para ulama membagi hak kepada tiga kelompok. Pertama, hak Allah murni, yaitu perbuatan yang dimaksudkan untuk memenuhi hak Allah (masyarakat umum). Di sini tidak ada pilihan lain dan mesti dijalankan. Kedua, hak manusia murni, yakni perbuatan untuk memenuhi hak manusia. Di sini ada pilihan untuk menjalankan atau tidak. Ketiga, hak Allah lebih kuat, disamakan dengan hak Allah murni. Keempat, hak manusia lebih kuat, disamakan dengan hak manusia murni. Klasifikasi ini biasa disederhanakan menjadi hak Allah dan hak manusia. Lihat: 'Abd al-Wahâb Khallâf, 'Ilmu Ushûl al-Fiqh (Kairo: Maktabah al-Da'wah al-Islâmiyah, 1376 H/1956 M), h. 210-216. 
Hai orang-orang yang beriman, diwajibkan atas kamu qishâsh berkenaan dengan orangorang yang dibunuh; orang merdeka dengan orang merdeka, hamba dengan hamba dan wanita dengan wanita. Maka barangsiapa yang mendapat suatu pemaafan dari saudaranya, hendaklah (yang memaafkan) mengikuti dengan cara yang baik, dan hendaklah (yang diberi maaf) membayar (diat) kepadayang memberi maafdengan cara yang baik (pula). Yang demikian itu adalah suatu keringanan dari Tuhan kamu dan suatu rahmat. Barangsiapa yang melampaui batas sesudah itu, maka baginya siksa yang sangat pedih.

Nabi SAW. bersabda:

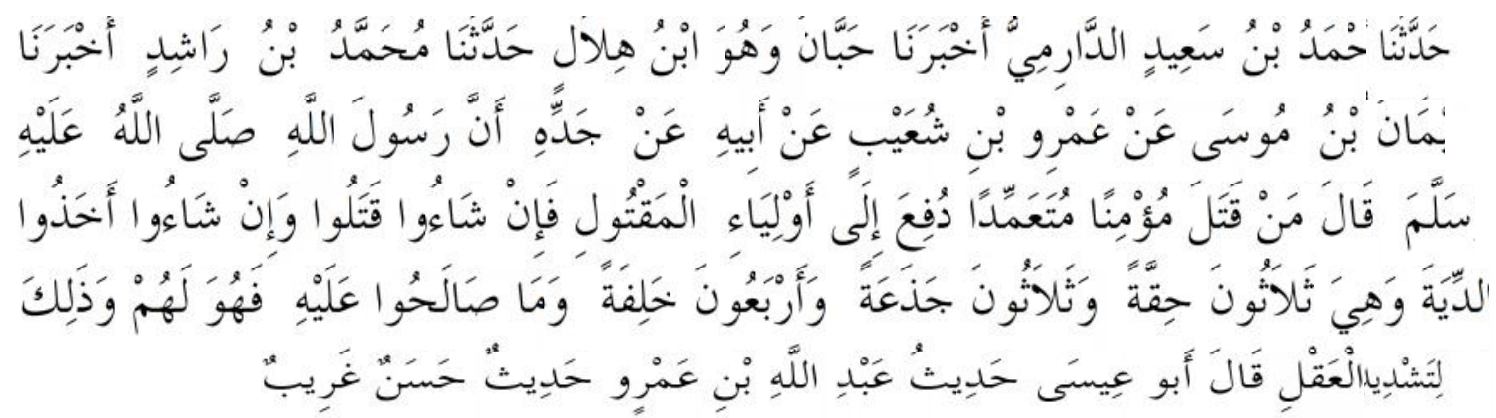

"Hadis dari Ahmad bin Sa'̂̂d al-Dârimî yang berasal dari $\underline{H}$ abbân, yakni Ibn Hilâl, dari Muhammad bin Râsyid, dari Sulaimân bin Mûsâ dari 'Amru bin Syu'aib, dari ayahnya, dari kakeknya, bahwa Rasulullah SAW bersabda: "Barangsiapa membunuh seorang mukmin dengan sengaja, urusannya terserah kepada para wali terbunuh. Jika mereka menginginkan, mereka dapat menuntut pembunuhan balasan (qishâsh). Jika wali terbunuh mau memaafkan, mereka berhak mengambil diyat, yakni 30 hiqqah, 30 jiz'ah, dan 40 khilfah (100 ekor unta). Apa saja yang mereka perdamaikan (ishlâh), maka adalah untuk mereka. Hal itu ditujukan untuk menguatkan atau meninggikan akal" (H.R. al-Tirmidzî). ${ }^{23}$

Jika tercapai ishlâh, dalam arti wali korban memaafkan pelaku, maka gugur hukuman qishâsh bagi pelaku. Sebagai gantinya, wali korban berhak menerima diyat darah dengan jumlah dan perincian sebagaimana tercantum di dalam hadis atau yang senilai. Kalau wali korban sepakat memaafkan juga diyat tersebut, maka gugur pula hukuman diyat bagi korban. Meskipun begitu, belum berarti pelaku bebas dari segala hukuman. Ada kemungkinan penguasa atau hakim menjatuhkan hukuman tambahan berupa ta'zir sebagai upaya perlindungan terhadap hak Allah (hak masyarakat). Menurut sebagian ulama, seperti Imam Mâlik, alLaits, dan ahli fiqih Madinah, pelaku pembunuhan sengaja yang dimaafkan oleh wali korban masih dapat dijatuhi hukuman ta'zir oleh hakim berupa 100 kali cambukan dan penjara satu tahun. Pendapat ini didasarkan kepada riwayat dari 'Umar bin Khathâb. Kebijakan ini dapat diterapkan karena yang dapat digugurkan oleh pemaafan atau ishlâh hanyalah hak perorangan, seperti hukuman qishâsh dan diyat. Sedangkan hak Allah (hak masyarakat)

${ }^{23}$ Muhammad bin 'Îsya Abû 'Îsya al-Tirmidzî, Sunan al-Tirmidzî, Taḥqîq Aḥmad Muhammad Syâkir, dkk, juz IV (Beirût: Dâr al-Ihyâ` al-Turâts al-'Arabî, t.t.) h.11. 
di dalam tindak pidana tidak dapat digugurkan sehingga dapat diwujudkan dengan penetapan hukuman ta'zir kepada pelaku. ${ }^{24}$ Sementara itu, sebagian ulama lain yang terdiri dari Imam al-Syafiî̀, Ahmad, dan Ishââ berpendapat kalau wali korban telah memaafkan pelaku pembunuhan sengaja, maka ia terbebas dari segala hukuman dan tidak ada keharusan bagi penguasa atau hakim untuk menerapkan hukuman tambahan berupa ta'zir. Sementara itu, Abû Tsaur berpendapat bahwa penguasa atau hakim berwenang memberikan hukuman pengajaran sekadar yang diperlukan apabila pelaku pembunuhan adalah orang yang terkenal dengan kejahatannya (residivis). Menanggapi perbedaan pendapat tersebut, Ibn Rusyd menyatakan bahwa pendapat yang membebaskan terpidana setelah pemaafan lebih kuat sebab penetapan hukuman mesti melalui tauqîf (penjelasan syara'), sementara tidak ditemukan tauqîf pada masalah ini. Pendapat yang membolehkan penambahan hukuman ta'zir setelah pemaafan hanya didasarkan kepada riwayat yang lemah. ${ }^{25}$

Dari penjelasan di atas, dapat diketahui bahwa penyelesaian perkara yang berada di wilayah hak perorangan dapat dilakukan melalui mekanisme perdamaian atau ishlâh termasuk di antaranya perkara qishâsh-diyat. Dengan demikian, perkara-perkara pelanggaran hak asasi manusia juga bisa diselesaikan dengan mekanisme perdamaian atau ishlâh $\underline{h}$ asalkan perkara-perkara tersebut menyangkut hak perorangan, bukan hak Allah atau hak masyarakat. Di samping itu, perdamaian atau ishlâh tersebut mesti dijalankan berdasarkan prinsipprinsip keadilan, ketulusan, kebenaran, dan tidak bertentangan dengan aturan syara'.

Jika diteliti lebih jauh, penyelesaian perkara melalui mekanisme ishlâh bukan hanya sekedar dibolehkan, melainkan juga dipuji dan dianjurkan. Kesan tersebut dapat dilihat dari ayat al-Qur'an dan hadis yang menjadi dasar hukum pembolehan ishlâh. Pada Q.S. al-Baqarah/2: 178, Allah SWT. menyatakan bahwa pemaafan dan pembayaran diyat secara baik (yakni ishlâh ) pada kasus pembunuhan merupakan keringanan (takhfif) dan rahmat dari Allah. Ungkapan tersebut menunjukkan bahwa penyelesaian perkara pembunuhan melalui ishlâh merupakan sesuatu yang positif dan terpuji. Pada hadis riwayat al-Tirmidzî di atas, Rasulullah SAW. menyatakan bahwa salah satu hikmah dari penyelesaian perkara pembunuhan melalui ishlâh (الَعقَـــــ dalam makna pengutamakan pertimbangan akal sehat dan kemaslahatan yang lebih besar. Penyelesaian perkara melalui ishlâh atau perdamaian memang lebih mengedepankan aspek rasionalitas dari pada aspek emosi yang sangat mungkin ketika itu diliputi oleh perasaan marah, sakit hati, kekecewaan mendalam, dan bahkan dendam.

Pujian Nabi SAW. tersebut menunjukkan bahwa penyelesaian perkara melalui mekanisme

\footnotetext{
${ }^{24}$ Abû al-Walîd Muhammad bin Aḥmad bin Muhammad bin Aḥmad Ibn Rusyd, Bidâyah alMujtahid wa Nihâyah al-Muqtashid, jilid II (Semarang: Thâhâ Putra, t.t.), h. 303; Ahmad Fathî Bahnasî, al-Siyâsah al-Jinâ'iyyah fí al-Syarî'ah al-Islâmiyyah (Kairo: Maktabah Dâr al-'Urûbah, 1357 H/1965 M), h.190 dan 'Abd al-Qadîr 'Audah, al-Tasyrî' al-Jinâ 'i al-Islâmî: Muqâranah bi alQanûn al-Wad’i (Beirut: Muassasah al-Risâlah, 1992), h. 773.

${ }^{25}$ Ibn Rusyd, Bidâyah al-Mujtahid, jilid II, h. 303.
} 
perdamaian merupakan sesuatu yang dianjurkan. Oleh sebab itu, Nabi SAW. menganjurkan wali korban untuk mempertimbangkan secara matang dan komprehensif terlebih dahulu sebelum memilih antara menuntut qishâsh, diyat, atau memaafkan pelaku pembunuhan secara keseluruhan. Pertimbangan tersebut tentu meliputi semua aspek yang terkait dengan peristiwa pidana, keadaan pelaku dan keluarganya, keadaan korban dan ahli waris, pandangan masyarakat, penegakan hukum dan keadilan, serta aspek-aspek lainnya. Anjuran mempertimbangkan dengan seksama kebijakan yang akan diambil tersebut termaktub antara lain pada hadis berikut.

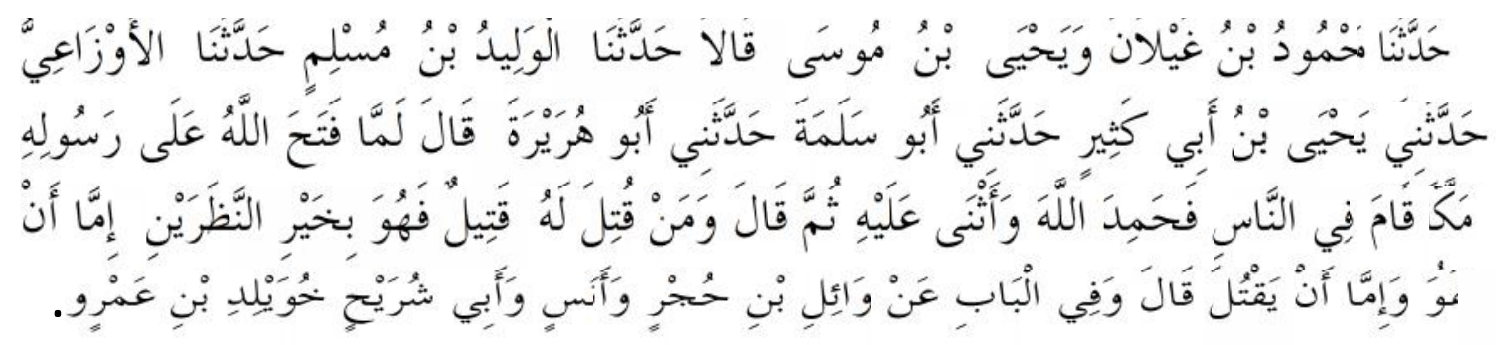

"Hadis disampaikan oleh Mậmûd bin Ghailân dan Yahya bin Mûsâ, keduanya menerima dari al-Walîd bin Muslim, dari al-Auzầ̂, dari Yahya bin Abî Katsîr, dari Abû Salamah, dari Abû Hurairah yang berkata bahwa ketika Allah menaklukkan Makkah bagi Rasulullah, Rasulullah berdiri di hadapan orang banyak, memuji dan memuliakan Allah, kemudian bersabda: "Barangsiapa mempunyai keluarga yang dibunuh, ia boleh memilih yang terbaik dari dua pertimbangan, yakni memaafkan (dalam riwayat lain: menerima diyat) atau menuntut hukuman mati (qishâsh). Pada bab ini adajuga riwayat lain melalui Wa 'il bin Hujrin, Anas, Abî Syuraih Khuwailid bin Amru”" (H.R. al-Bukhârî, Muslim, al-Tirmidzî, Abî Dâud al-Nasâ' î, Ibn Mâjah, dan Ahmad). ${ }^{26}$

Penyelesaikan melalui ishlâh menghasilkan berbagai manfaat. Ishlâh adalah hasil kompromi sehingga lebih mudah diterima, menghapus dendam, dan tidak ada pihak yang merasa dikalahkan. Ishlâh lebih dapat menuntaskan masalah secara adil dan bermartabat, sebab ishlâh tidak hanya mempertimbangkan aspek hukum, tetapi juga aspek kemanusian, seperti masa depan korban dan keluarga, perbaikan hubungan silaturahim, dan sebagainya. Ishlâh memungkinkan korban atau wali/ahli waris menerima denda/kompensasi sehingga membantu secara ekonomis dan psikologis. Sementara pelaku berkesempatan bertobat dan memperbaiki diri. Oleh karena itu, ishlâh dikatakan mendatangkan rahmat, berkah, dan dianjurkan Allah SWT. dan Rasul-Nya.

${ }^{26} \mathrm{Al}$-Tirmidzî, Sunan al-Tirmidzî, jilid IV, h. 21. Hadis dengan redaksi matan yang hampir sama terdapat pada Shahîh al-Bukhârî, jilid I dan II, h. 53 dan 857, Shahîh Muslim, jilid II, h. 988, Sunan Abî Dâud, jilid IV, h. 172, Sunan al-Nasấi, jilid VIII, h. 38, Sunan Ibn Mâjah, jilid II, h. 876, dan Musnad Ahmad, jilid II, h. 238. 
MIQOT Vol. XXXV No. 2 Juli-Desember 2011

\section{Penutup}

Dari pembahasan di atas dapat diketahui bahwa kasus-kasus pelanggaran hak asasi manusia, dengan kriteria-kriteria sebagaimana ditentukan di dalam peraturan perundangundangan Indonesia, telah pernah terjadi dan diselesaikan pada sistem peradilan sejak masa Nabi SAW. Penyelesaian kasus pelanggaran hak asasi manusia dilaksanakan dengan tiga metode. Pertama, metode berperkara biasa di pengadilan yang diakhiri dengan keputusan hakim. Kedua, metode berperkara biasa di pengadilan yang diakhiri dengan ishlâh (perdamaian). Ketiga, metode pengungkapan kebenaran dan rekonsiliasi para pihak, tanpa melalui proses berperkara di pengadilan.

Metode yang diakhiri perdamaian lebih dihendaki dan dipuji di dalam hukum Islam, sepanjang menyangkut masalah hak perorangan. Metode yang pertama dan kedua, secara umum, memiliki kesamaan dengan metode penyelesaikan perkara pada Pengadilan Hak Asasi Manusia di Indonesia, meskipun berbeda dalam ruang lingkup perkara yang dapat diselesaikan. Sedangkan metode ketiga sejalan dengan yang dilaksanakan Komisi Kebenaran dan Rekonsiliasi, dengan ruang lingkup perkara yang juga berbeda.

\section{Pustaka Acuan}

Abû Dâud, Sulaimân bin al-Asyats al-Sijistânî al-Azadî. Sunan Abî Dâud, ditahqîq oleh Muhammad Muhyî al-Dîn 'Abd al-

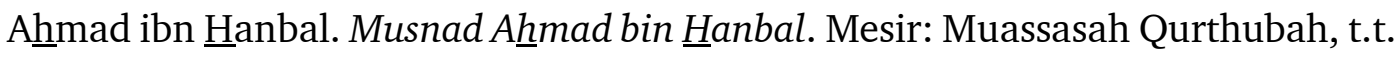

Al-Asqalânî, Ibn Hajar. Fath al-Bârî bi Syarh Shahîhh al-Bukhârî, ditahqîiq oleh Muhammad Fu'ad 'Abd al-Bâqî. Beirût: Dâr al-Ma'rifah, t.t.

'Audah, 'Abd al-Qadîr. al-Tasyrî' al-Jinâ'i al-Islâmî: Muqâranah bi al-Qanûn al-Wad'i. Beirut: Muassasah al-Risâlah, 1992.

Al-Bahnasî, Ahmad Fathîi. al-Siyâsah al-Jinâ'iyyah fî al-Syarî‘ah al-Islâmiyyah. Kairo: Maktabah Dâr al-'Urûbah, 1357 H/1965 M.

Al-Bakr, Muhammad 'Abd al-Rahmân. al-Sulthah al-Qadhâ'iyyah wa al-Syakhshiyyah alQâdhî. t.tp.: al-Zahrâ' li al-A'lam al-Arabî, 1408/1988.

Al-Bukhârî, Muhammad bin Ismâ'îl Abû 'Abdillâh. Shahîh al- Bukhârî. Beirût: Dâr Ibn Katsîr, 1408/1987.

"Pengadilan Paling Akhir", dalam Gatra. Jakarta, 29 Januari 2000.

Hamzah, Andi. Asas-Asas Hukum Pidana. Jakarta: PT. Rineka Cipta, 1994.

"Majlis Kabulkan Pemberian Kompensasi Korban Tanjung Priok", dalam Hukum Online.Com Jakarta, 21 Agustus 2004.

Ibn ㅂibbân, Muhammad al-Taimimî. Shahîh Ibn ㅂibbân. Beirût: Mu'assasah al-Risâlah, $1414 \mathrm{H} / 1993 \mathrm{M}$.

Ibn Hisyâm, 'Abd al-Malik. al-Sîrah al-Nabawiyyah, Tahqîq Thâhâ 'Abd al-Raûf Sa'îd. Beirût: Dâr al-Jail, 1411. 
Ibn Mâjah, Muhammad bin Yazîd Abû 'Abdillâh. Sunan Ibni Mâjah, Tahqîq Muhammad Fu'âd 'Abd al-Bâqî. Beirût: Dâr al-Fikr, t.t.

Ibn Qudamah al-Maqdisî. al-Mughnî. Beirût: Dâr al-Kutub al-'Ilmiyyah, 1994.

Ibn Rusyd, Abû al-Walîd Muhammad bin Aḥmad bin Muhammad bin Aḥmad. Bidâyah al-Mujtahid wa Nihâyah al-Muqtashid. Semarang: Thâhâ Putra, t.t.

“Pembantai Muslim Bosnia Tewas di Sel,” dalam Indopos, Jakarta, 12 Maret 2006.

Kanter, EY. dan S.R. Sianturi. Asas-Asas Hukum Pidana di Indonesia dan Penerapannya. Jakarta: Storia Grafika , 2002.

Khallâf, 'Abd al-Wahâb. 'Ilmu Ushûl al-Fiqh. Kairo: Maktabah al-Da'wah al-Islâmiyah, $1376 \mathrm{H} / 1956 \mathrm{M}$.

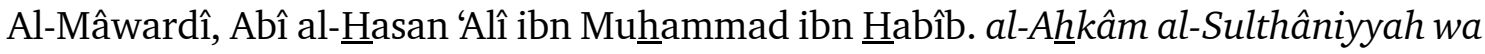
al-Wilâyah al-Dîniyyah. Beirût: Dâr al-Fikr, 1380 H/1960 M.

Muladi. "Kejahatan terhadap Kemanusiaan", Makalah disampaikan pada Pelatihan HAM bagi Hakim dan Hakim Ad Hoc di Hotel Santika Jakarta 7 Nopember 2001. Jakarta: Departemen Kehakiman dan HAM R.I., 2001.

Muladi. "Prospek Pengaturan Pengadilan Hak Asasi Manusia (HAM) di Indonesia", Makalah pada Seminar Nasional Rancangan Undang-Undang Pengadilan HAM. Jakarta, 16 Februari 2000.

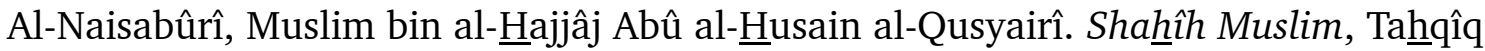
Muhammad Fu'âd 'Abd al-Bâqî. Beirût: Dâr al-Ihyâ' al-Turats al-'Arabî, t.t.

Al-Nasâ'î, Sunan al-Nasâî̀. Halb: Maktab al-Mathbû'ât al-Islamiyyah, 1406 H/1986 M.

Nusantara, Abdul Hakim Garuda. "Mengadili Kasus-Kasus Pelanggaran Hak Asasi Manusia: Pengalaman Beberapa Negara", Makalah pada Seminar Nasional Rancangan UndangUndang tentang Pengadilan Hak Asasi Manusia. Jakarta: Direktorat Jenderal Hukum dan Perundang-undangan Departemen Hukum dan Perundang-undangan R.I., 16 Februari 2000.

Prodjodikoro, Wirjono. Asas-Asas Hukum Pidana di Indonesia. Bandung: Eresco, 1989.

Sâbiq, al-Sayyid. Fiqh al-Sunnah. Beirût: Dâr al-Fikr, 1403/1983.

Soegianto, Djoko. “Usaha untuk Mengenal Pengadilan HAM”, Makalah Pelatihan HAM bagi Calon Hakim dan Hakim Ad Hoc di Hotel Santika 410 Nopember 2001. Jakarta: Departemen Kehakiman dan HAM R.I., 2001.

Statute of the International Tibunal for Former Yugoslavia, Adopted 25 May 1993 as Amended 13 May 1998.

Statute of the International Tibunal for Rwanda, 1994.

Syaddad, Badar al-Dîn. Dalâil al-Ahkkâm. Beirût: Dâr al-Kutub al-'Ilmiyyah, 1991.

Al-Thârifî, Nâshir ibn 'Âqil ibn Jâbir. al-Qadhâ' fi ‘Âhdi 'Umar ibn al-Khaththâb. Jeddah: Dâr al-Madanî, 1986.

Al-Tirmidzî, Muhammad bin ‘Îsya Abû ‘̂̂sya al-Tirmidzî. Sunan al-Tirmidzî, Tahquîq Ahmad Muhammad Syâkir, et al. Beirût: Dâr al-Ihyâ' al-Turâts al-'Arabî, t.t. 